\title{
UVODNIK
}

\section{DVAJSET LET REFLEKSIVNE PRAKSE}

Tokratna številka revije zaokrožuje 20-letno pot izhajanja, kar je za naše razmere razveseljiv dosežek. Revija je nastala in nastaja $\mathrm{z}$ veliko projektnega in prostovoljnega dela mnogih strokovnjakov in strokovnjakinj. Na svoj način to kaže na vitalnost področja in zavzetost ter pripravljenost ljudi za sodelovanje $\mathrm{v}$ razvoju revije po načelu etike »skrbnosti za stroko « in ne tekmovalnosti. Takšno delovanje izhaja iz ene od temeljnih usmeritev revije, to je opozarjanje na probleme družbenega okolja, kakršen je finančni totalitarizem, in igre družbene moči, sledeč idejam Freireja, Illicha, Mezirowa. Hvala vsem, ki prispevate $\mathrm{v}$ mrežo spoznanj in dobrih praks kot kritični bralci, avtorji, recenzenti, svetovalci, uredniki, oblikovalci, lektorji, upravljavci, donatorji, založniki.

V uvodniku prve dvojne številke leta 1995 je bilo zapisano, da se razmere v izobraževanju odraslih hitro spreminjajo. Danes lahko rečemo, da se izjemno hitro spreminjajo in da smo vse bolj del pulzirajočih omrežij, ki so negotova in polna izzivov. Tudi v tej številki je nekaj člankov - npr. o izobraževanju invalidov oz. ljudi s posebnimi potrebami, brezposelnih, o ovirah pri vključevanju v izobraževanje - v katerim pišemo o tem, da je potrebno veliko znanja, prožnosti in iznajdljivosti ter osebne zavzetosti, da bi sledili spremembam in razvijali svoje refleksivne prakse. Spreminja se odnos do identitete in znanja, spreminjajo se uporaba, nastajanje, legitimiranje in prenos znanja. Identiteta, ki jo razumemo kot »biti oseba v svetu«, in učenje kot spreminjanje identitete (gl. Illeris, 2014) sta kompleksna in še dokaj neraziskana procesa, ki pomenita izziv za andragogiko. V predstavitvi knjig in odmevih iz prakse $\mathrm{v}$ sklepnem delu te številke pa opozarjamo na dva novejša pogleda, ki se navezujeta na kompleksnost učenja $\mathrm{v}$ spreminjajočem se okolju. Prvi je izobraževanje in raziskovanje učenja v starosti, drugi je razvoj refleksivnega starševstva. Oboje odseva spekter novih področij, povezanih s pojavi, ki jih je treba znova kritično premisliti, da ne bi s praksami zgolj sledili potrošništvu ali utrjevali stereotipov. Kritičen je tudi premislek v članku o priznavanju znanja. Analiza razgrne probleme pri pojavih, ki se na prvi pogled zdijo samoumevni in nujni za razvoj, a niso vedno takšni.

V intervjuju, ki ga objavljamo na naslednjih straneh, profesorica Ana Krajnc poudarja, da živimo v časih, ki se razlikujejo od tako imenovanega industrijskega obdobja, ko sta bili učenje in izobraževanje namenjeni predvsem povečevanju produkcije materialnih predmetov in ohranjanju hierarhične delitve na fizično in umsko delo, na praktično in teoretsko znanje. $\mathrm{V}$ sodobnosti sta pomembna razvoj identitete in povezovanje raznovrstnega 
znanja. Podobno je tudi profesor Tine Hribar (1985) zapisal, da je bilo 19. stol. stoletje produkcije, 20. stol. stoletje organizacije, 21. stol. pa je (bo) stoletje orientacije. Zdi se, da iz obdobja, ko je bilo učenje namenjeno predvsem reproduciranju in industrijskemu proizvajanju predmetov, prehajamo v obdobje ustvarjalnosti, ko sta pomembna nabor zmožnosti, zgrajen iz védenja, odgovornosti vsakega posameznika, sodelovalnosti, dialoškosti in delovalnosti (agency), ter prepletanje raziskovanja, umetnosti, intuicije in refleksivnega učenja pri iskanju novih poti.

Napredek (ali celo preživetje?) označujejo kultura skrbnosti in trajnostno naravnan razvoj, ki ga imenujemo tudi porazvoj ali ekološki socializem, in človek, ki pristopa k svojemu življenju kot k nenehnemu ustvarjanju. Biografija postane ustvarjalna zgodba ali refleksivna avtobiografija. V vsakem obdobju življenja ima človek mnogo možnosti, ob katerih nastajajo novi pomeni in delovanje. Za tovrstno učenje potrebuje zmožnost za »orientacijo《 in pogum, da sprejme negotovost. Autopoiesis in identizacija (gl. Tisdell, 2012) sta procesa transformativnega biografskega učenja, ki poleg transmisije uporabljata tudi domišljijo, transformacijo in transgresijo, zato ni presenetljivo, da je trenutno veliko raziskav s področja transformativnega učenja. Učenje ni namenjeno ščitenju hierarhičnih položajev, značilnih za hierarhično organizirano družbo, učenje je namenjeno odkrivanju ciljev, smisla življenja, bivanja v svetu. V članku o empatiji avtorica predstavi možnosti za razvijanje zmožnosti soočanja s svojimi čustvi in čustvi drugih, kar postaja tudi del sodobnih poti transformativnega učenja. Najpomembnejši za tako imenovani porazvoj je ozaveščen posameznik, ki zna komunicirati z drugim, ki se $\mathrm{z}$ drugim srečuje v dialogu, ki svoj Jaz postavi v odnos s Ti drugega. Komuniciranje ni nikoli nevtralna izmenjava, temveč je vedno odnos. Le želimo si lahko, da odnos gradi tudi skupnost.

Svojevrstna skupnost je nastajala tudi ob izdajanju Andragoških spoznanj. Revija želi s svojim delovanjem prispevati $\mathrm{k}$ dialogu in izmenjavi (spo)znanj. S tem pa ustvarja bogato mrežo avtorjev, bralcev, kritikov, odločevalcev in donatorjev, med katerimi nastajajo odnosi in se razvija komunikacija. Nekateri odnosi so dialoški, nekateri polemični, vendar vsi poskušajo biti prostor za (spo)znanja in pogosto tudi refleksivnega učenja iz napak. Zato se trudimo, da ohranjamo ustvarjalne odnose, razvijamo možnosti za odprt dialog in nehierarhična razmerja. Enako resno jemljemo študentske prispevke kot prispevke uveljavljenih avtorjev in avtoric, kar je dogovor že iz časa prvega uredniškega odbora.

Prvi uredniški odbor revije so sestavljali Milena Ažman, Jordan Berginc, Melita Cimerman, Nada Češnovar, Jožko Čuk (Gospodarska zbornica Slovenije), Jasna Dominko Baloh (Andragoško društvo Slovenije), Zoran Jelenc (Andragoški center Slovenije), Janez Jereb, Božo Kočevar, Sašo Niklanovič, Danica Purg, Dimitrij Rupel, Ivan Svetlik, Pavel Zgaga, Pavel Hartel, Liam Carey, Paolo Federighi, Peter Jarvis, glavna urednica Ana Krajnc in odgovorna urednica Danijela Brečko. Mogoče lahko hudomušno dodamo, da trije Pavli v prvem uredniškem odboru nakazujejo usmerjenost revije v ozaveščanje in uzaveščanje. Vedno so bile s svojimi predstavniki v uredniškem odboru zastopane ključne ustanove: Andragoški center Slovenije, Andragoško društvo Slovenije, Gospodarska 
zbornica Slovenije, fakultete, ki so se ukvarjale z raziskovanjem izobraževanja odraslih, ljudske univerze. Raznovrstno članstvo je zagotavljalo ustrezno okolje, ki je skrbelo za senzibilizacijo družbe s pomenom učenja in izobraževanja odraslih.

\section{LITERATURA}

Hribar, T. (1985). Moč znanosti. Ljubljana: Delavska enotnost.

Illeris, K. (2014). Transformative Learning and Identity. London: Routledge.

Nicolini, D., Gorli, M. in Scaratti, G. (2015). Reflexivity in practice: Tools and conditions for developing organizational authorship. Human Relations (v tisku).

Tisdell, E. J. (2012). Themes and variations in transformational learning. V E. W. Taylor, P. Cranton (ur.), The Handbook of Transformative Learning (str. 21-36). San Francisco: Jossey-Bass.

Nives Ličen 